\title{
DRIFTLESS AREA KARST OF NORTHWESTERN ILLINOIS AND ITS EFFECTS ON GROUNDWATER QUALITY
}

\author{
Samuel V. Panno \\ Illinois State Geological Survey, 615 E. Peabody Drive, Champaign, IL, 61820, USA, s-panno@illinois.edu
}

\author{
Walton R. Kelly \\ Illinois State Water Survey, 2204 Griffith Drive, Champaign, IL, 61820,USA, wkelly@illinois.edu
}

\begin{abstract}
The bedrock aquifer of the Driftless Area of northwestern Illinois is Ordovician Galena Dolomite. Previous work by the authors and others showed that the geology and hydrogeology of this area fall well within the definition of karst. Bedrock in the study area has been shown to be extensively fractured and creviced; karst features in the county are dominated by solution-enlarged crevices from 0.4 inches to 3 feet $(1.0 \mathrm{~cm}$ to $0.9 \mathrm{~m})$ wide within most road cuts and quarries examined. Other karst features include cover-collapse sinkholes ranging from 3 to 25 feet $(0.9$ to $7.6 \mathrm{~m})$ in diameter overlying Galena Dolomite, karst springs and crevice caves.
\end{abstract}

A preliminary evaluation of the groundwater quality Jo Daviess County in the Driftless Area of northwestern Illinois was conducted to assess the susceptibility of the Galena Dolomite aquifer to surface-borne contaminants. This was done by evaluating available groundwater quality data from published sources and the Illinois State Water Survey Groundwater Quality Database (i.e., wells and springs), and also by sampling 11 private wells across the county and analyzing for inorganic chemistry, dissolved organic carbon, stable isotopes and tritium. We found that groundwater in the study area is of a $\mathrm{Ca}-\mathrm{Mg}-\mathrm{HCO}_{3}$ type as would be expected for an aquifer dominated by dolomite. In parts of the county, the upper part of the carbonate-hosted aquifer contains elevated concentrations of chloride, nitrate and potassium. Likely contamination sources are anthropogenic and include road salt, potash and nitrogen fertilizers, and livestock/ human waste. The presence of these contaminants suggests movement of surface-borne contaminants into the aquifer and into wells screened at depths ranging from 65 to 150 feet (20 to $46 \mathrm{~m}$ ).

Historic data reveal stratification of surface-borne contaminants (greatest concentrations nearest the surface) within the fractured and creviced aquifer to a depth of about 300 feet $(91 \mathrm{~m})$. Nitrate- $\mathrm{N}\left(\mathrm{NO}_{3}-\mathrm{N}\right)$ concentrations in karst springs are typically between 10 and $13 \mathrm{mg} / \mathrm{L}$, but can exceed $30 \mathrm{mg} / \mathrm{L}$. Because the predominant land use in the study area is row-crop agriculture, it is likely that much of the $\mathrm{NO}_{3}-\mathrm{N}$ is derived from $\mathrm{N}$-fertilizer. In the 11 water well samples, $\mathrm{NO}_{3}-\mathrm{N}$ concentrations ranged from $<0.04$ (detection limit) to $5.4 \mathrm{mg} / \mathrm{L}$ and concentrations were clearly related to tritium. Specifically, $\mathrm{NO}_{3}^{-}$ $\mathrm{N}$ concentrations in groundwater containing less than $3 \mathrm{TU}$ were below detection $(0.04 \mathrm{mg} / \mathrm{L})$, and above 3 TU, NO3-N and tritium were positively correlated. This relationship suggests a nonpoint source of $\mathrm{N}$ and denitrification within the aquifer. Chloride $\left(\mathrm{Cl}^{-}\right)$concentrations in karst springs were between 15 and $25 \mathrm{mg} / \mathrm{L}$ above background concentrations ( 1 to $15 \mathrm{mg} / \mathrm{L}$ ). Water wells samples had lower $\mathrm{Cl}^{-}$concentrations with 7 of 11 wells below background (ca. $15 \mathrm{mg} / \mathrm{L}$ ), although the concentration in the shallowest well was $110 \mathrm{mg} / \mathrm{L}$ and was probably derived from road salt. Overall, the groundwater quality of the Galena Dolomite aquifer in Jo Daviess County is what would be expected in an open, dolomitedominated karst aquifer.

\section{Introduction}

Groundwater in karst regions of the Midwestern US is typically $\mathrm{Ca}-\mathrm{HCO}_{3}$ to $\mathrm{Ca}-\mathrm{Mg}-\mathrm{HCO}_{3}$ type water that can have relatively high levels of surface-borne contaminants, especially at shallow depths. Typical contaminants in wells and springs include sodium $(\mathrm{Na})$, potassium $(\mathrm{K})$, chloride $\left(\mathrm{Cl}^{-}\right)$, nitrate-nitrogen $\left(\mathrm{NO}_{3}-\mathrm{N}\right)$ and enteric bacteria (e.g., Panno et al. 1996; Hackley et al. 2007).

The Driftless Area of northwestern Illinois was mapped in the mid-1990s as karst by Weibel and Panno (1997) and Panno et al. (1997). Domestic wells in Jo Daviess County get their water primarily from the Galena Dolomite at depths less than 250 feet $(76 \mathrm{~m}$ ) (Frankie and Nelson 2002). While the degree of karstification has been well established (Panno et al. 2015a,b,c; Luman and Panno 2015), its effects on groundwater quality in the area are uncertain, although Panno and Luman (2008) explored this to a limited extent. They found that $\mathrm{Cl}^{-}$and $\mathrm{NO}_{3}-\mathrm{N}$ concentrations in private and public wells (most are cased more than 100 feet below the surface) in the county were as high as 55 and $31 \mathrm{mg} / \mathrm{L}$, respectively. These concentrations are well above the 
upper background threshold concentrations (1 to 15 $\mathrm{mg} / \mathrm{L}$ for $\mathrm{Cl}^{-}$and 0 to $2.5 \mathrm{mg} / \mathrm{L}$ for $\mathrm{NO}_{3}-\mathrm{N}$ ) for freshwater aquifers in the northern two-thirds of Illinois (Panno et al. 2006a, b). Potential sources include both urban and rural contaminants such as road salt $\left(\mathrm{Cl}^{-}\right)$, nitrogen fertilizer $\left(\mathrm{NO}_{3}-\mathrm{N}\right)$, and animal waste and septic effluent (both $\mathrm{Cl}^{-}$and $\mathrm{NO}_{3}-\mathrm{N}$ ). Stratification of concentrations of both $\mathrm{NO}_{3}-\mathrm{N}$ and $\mathrm{Cl}^{-}$was observed.

In order to determine the susceptibility of the shallow karst aquifer to groundwater contamination in the study area, we gathered water quality data from historic sources (Illinois State Water Survey (ISWS) Groundwater Quality Database), a recent study of six karst springs in northeastern Jo Daviess County (Maas 2010), and from sampling 11 domestic shallow water wells across the county. The objectives of this investigation were to establish a preliminary range and background for major cations and anions, and conduct a preliminary evaluation of the existing water quality in the Driftless Area. We also analyzed well water samples for tritium to get a sense of the residence time of groundwater in the study area and compare tritium to selected ions that may be introduced by surface-borne contamination.

\section{Geology and Hydrogeology}

Jo Daviess County lies within the Driftless Area of northwestern Illinois; the county, for the most part, lacks glacial drift that covers the bedrock of most of the upper Midwestern U.S. (Figure 1). However, glacial till is exposed along U.S. Route 20 between Galena and East Dubuque (Willman and Frye 1970; D. Kolata, personal communication, 2014), as well as a small area of glacial till in an isolated portion of the far eastern part of the county. Bedrock consists of Middle-Ordovician age (443 - $490 \mathrm{Ma})$ carbonate rocks of the Galena-Platteville Group, thin remnants of the Ordovician-age Maquoketa Shale, and Silurian dolomite (412 - $443 \mathrm{Ma})$ whose resistant rock caps the mounds and highlands of the county (Figure 2).

Tectonic compression and extension occurred in this area during and following the formation of the Wisconsin Arch that began in Cambrian time (490 - $543 \mathrm{Ma})$ and continued to be active in late Silurian or Devonian time (354- $417 \mathrm{Ma})$ (Nelson 1995). As a result of compression and extension, bedrock along the Wisconsin Arch has a well-developed vertical joint system. Heyl et al. (1959) stated that "All the rock formation in the [Upper Mississippi Valley mining] district [most of Jo Daviess County] contain well-developed vertical and inclined joints (Figure 3). The vertical joints are traceable for as much as 2 miles $(3.2 \mathrm{~km})$ horizontally, and for as much as 300 feet $(91 \mathrm{~m})$ vertically. Joints are especially

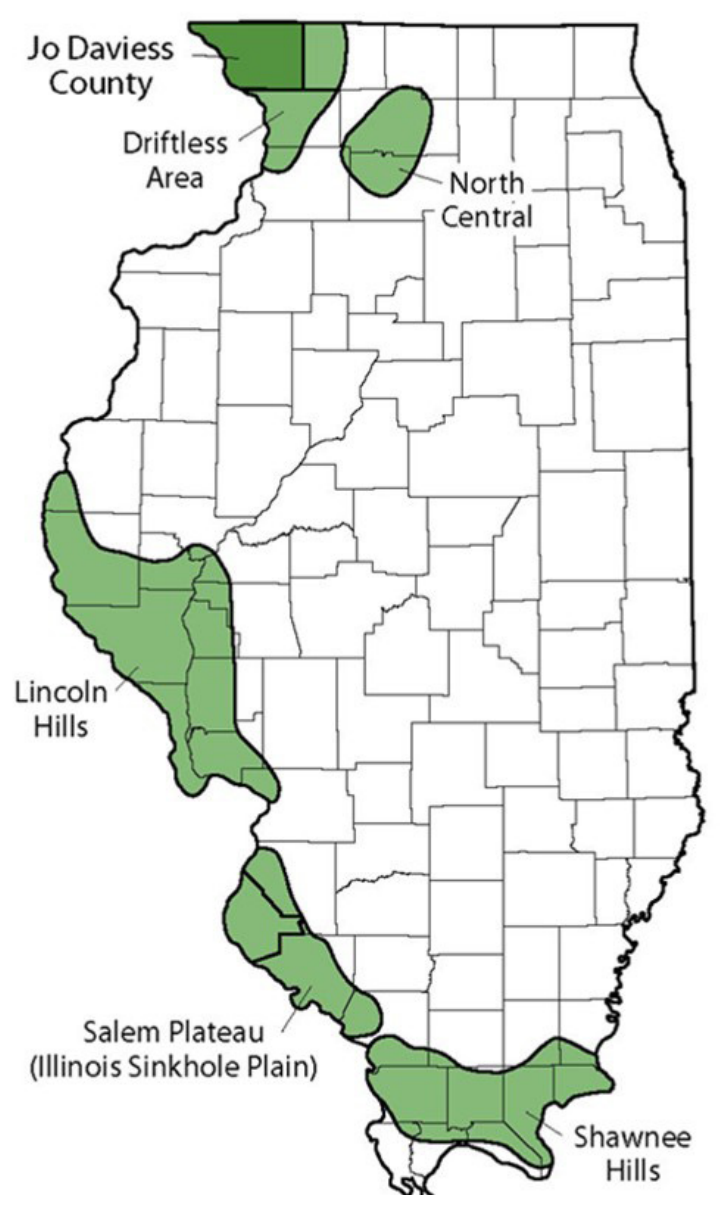

Figure 1. Karst areas of Illinois, USA. The study area is the Driftless Area in the northwestern corner of the state (modified from Weibel and Panno 1997).

well developed in the Galena Dolomite." Trowbridge and Shaw (1916) stated that crevices within the Galena Dolomite "... are frequently encountered in wells, and drilling tools are sometimes lost in them."

In the mid-1990s, the Illinois State Geological Survey (ISGS) identified Jo Daviess County as karst (Weibel and Panno 1997; Panno et al. 1997) (Figure 1). Subsequent work by McGarry and Riggs (2000) identified most of Jo Daviess County as having “.... a very high aquifer sensitivity because fractured dolomite bedrock aquifers lie beneath the glacial drift or loess. Areas where dolomite bedrock is exposed are most sensitive." The main karst water-bearing formation in the county is the Galena-Platteville Group. Silurian dolomite is also karstified, but is rarely used as an aquifer in the county. Ekberg (2008) subdivided the secondary porosity of the Galena-Plattville Group into matrix, fracture and conduit porosity. These subdivisions are supported by spring hy- 


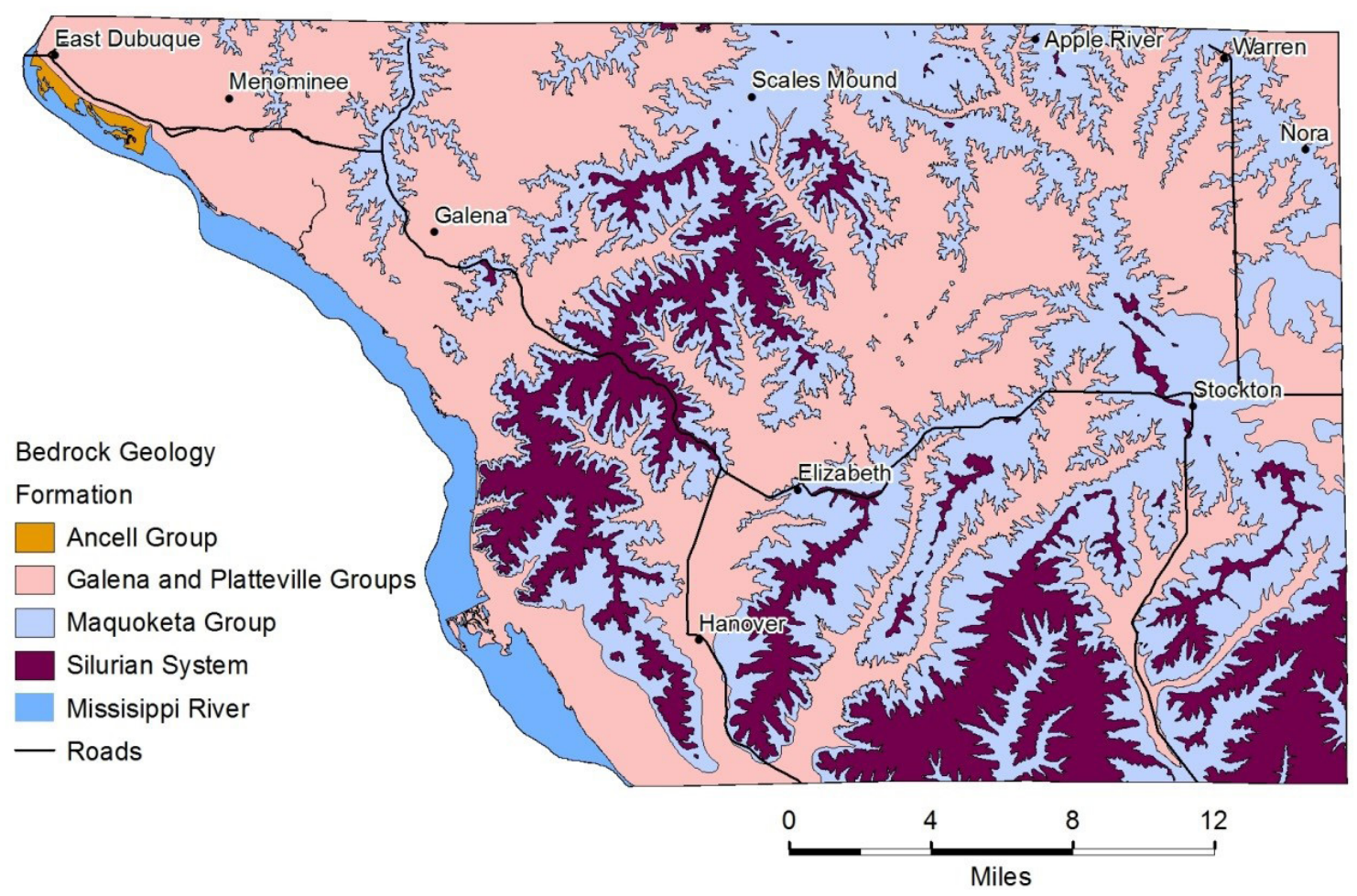

Figure 2. A generalized geologic map of Jo Daviess County (modified from McGarry and Riggs 2000).

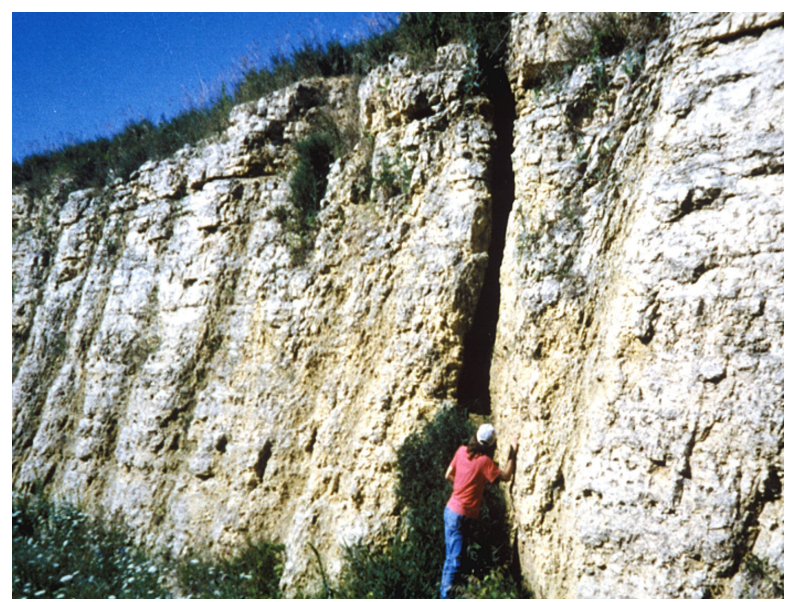

Figure 3. Crevice in Galena Dolomite along road cut just east of Jo Daviess County. Photograph by S.V. Panno.

drographs and drawdown curves from aquifer tests that support a triple porosity aquifer. The fracture porosity through which groundwater flows consists of northeastand northwest-trending vertical fractures (consistent with Heyl et al. 1959), and bedding planes (Ekberg 2008).

Panno and Luman (2008) examined sinkholes and the abundant secondary porosity (crevices) exposed along

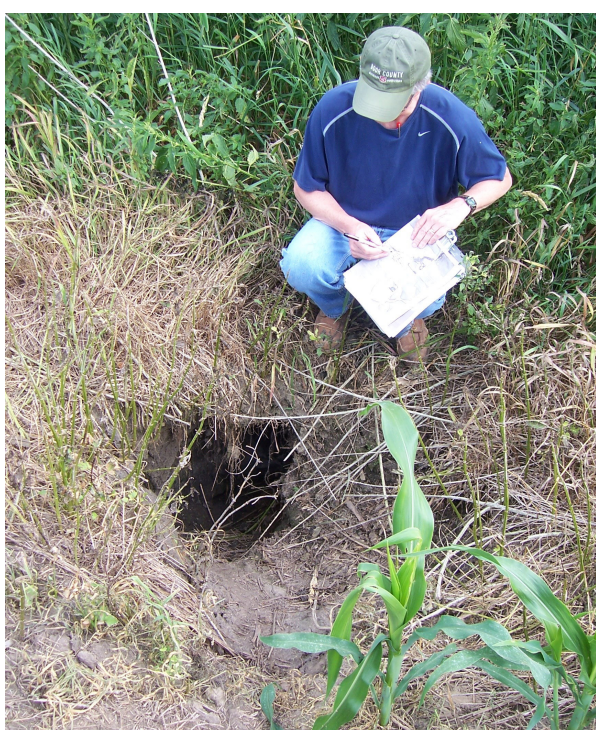

Figure 4. Sinkholes are relatively small in Jo Daviess County due to the relatively shallow soils. Within croplands, these features are easily buried.

road cuts and in quarries in eastern Jo Daviess County and concluded that the Galena Dolomite constitutes a karst aquifer. While cover-collapse sinkholes are present over the Galena Dolomite, they are typically small due 
to the thin soils of the area and are easily buried (albeit temporarily) in croplands (Figure 4). However, because of their presence, the county falls into a "medium" to "high" category of aquifer vulnerability as outlined by Lindsey et al. (2010).

\section{METHODS Groundwater Chemistry}

Groundwater chemistry data from private wells and karst springs in eastern Jo Daviess County were available through the ISWS Groundwater Quality Database described in Panno and Luman (2008), and from Maas (2010), respectively. In addition, 11 domestic shallow wells were sampled across the county (one in September, 2013, the other ten in June 2014) and analyzed for dissolved cations, anions, dissolved Kjeldahl N (DKN), ammonia, dissolved organic carbon (DOC), D/H and ${ }^{18} \mathrm{O} /{ }^{16} \mathrm{O}$ isotopic ratios, and bacterial indicators. Groundwater samples from the 10 wells sampled in June 2014 were analyzed for tritium.

Wells were purged for at least 15 minutes until field parameters (temperature, $\mathrm{pH}$, dissolved oxygen (DO), specific conductance $(\mathrm{SpC})$ and oxidation-reduction potential (ORP) stabilized. The field parameters were measured using a multisonde (Hydrolabß, Loveland, CO). Samples designated for chemical analyses were filtered through $0.45-\mu \mathrm{m}$ membranes, placed in polyethylene or glass bottles and stored at $4^{\circ} \mathrm{C}$ prior to analysis. All samples were transported in ice-filled coolers to the laboratory, and kept refrigerated until analysis. Analyses for inorganic chemicals were conducted in accordance with standard methods (APHA, AWWA, WEF 1999) at the ISWS using standard methods.

Sterile techniques were used for samples collected for bacterial indicators (total coliform and Eschericia coli). Outside spigots were flame sterilized then water was collected in sterilized bottles and stored in ice-filled coolers before transporting to the analytical laboratory the same day. Bacterial indicators were determined using the Colilert method (IDEXX 2013) at the City of Dubuque Laboratory, Dubuque, Iowa.

Tritium was analyzed using electrolytic enrichment (Ostlund and Dorsey 1977) and liquid scintillation counting as described in Hackley et al. (2007). Results are reported in tritium units.

\section{Results and Discussion Other Hydrologic Features}

Springs are a common feature throughout Jo Daviess County and the locations of some have been mapped by Reed (2008) and Maas (2010). The only available data on the chemical composition of springs in the county are from Maas (2010) for six springs in northeastern Jo Daviess County within the Warren Quadrangle. The springs lay along prominent lineaments identified in this investigation and are consistent with discharge of groundwater along bedrock crevices where the overburden thins near stream valleys. Groundwater, under hydrostatic pressure, would be able to breach land surface in low-lying areas with relatively thin overburden (usually near streams). Bedrock springs typically appear to be large circular to elliptical depressions with small sections breached, providing openings through which the spring water discharges to a nearby stream.

\section{Chemical Composition of Groundwater}

Because spring water in karst regions is an amalgam of groundwater from various sources, the chemical composition of spring water is useful in characterizing background concentration ranges of constituents and trends for contaminants (Table 1). The overall chemical composition of groundwater and relationships between and among selected cations and anions were used to identify the source(s) of contaminants. Background concentration ranges of selected ions are useful for comparing natural compositions of surface water and groundwater with waters that have been affected by anthropogenic and/or natural contamination. When making such comparisons, one must be aware that, for example, concentrations of $\mathrm{Na}, \mathrm{Cl}^{-}$and $\mathrm{NO}_{3}-\mathrm{N}$ that are somewhat elevated above background do not constitute water that is harmful to humans or to natural flora and fauna of an area. It does, however, indicate that surface-borne contaminants from land-use activities have entered groundwater and will ultimately discharge to surface waters. Further, it has been shown that elevated concentrations of $\mathrm{Na}$ and $\mathrm{Cl}^{-}$ can be deleterious to vegetation (e.g., Panno et al. 1999), aquatic organisms (e.g., Kelly et al. 2012), can impart a salty taste to drinking water at $\mathrm{Cl}^{-}$concentrations exceeding $250 \mathrm{mg} / \mathrm{L}$, and elevated $\mathrm{Na}$ concentrations in drinking water may be a problem for people with high blood pressure (USEPA 2014). Nitrate-N concentrations greater than $10 \mathrm{mg} / \mathrm{L}$ in drinking water have been shown to cause methemoglobinemia (blue-baby syndrome) and may be linked to stomach cancer (O'Riordan and Bentham 1993). For the purposes of this investigation, we considered concentrations exceeding the upper end of background as anthropogenic tracers that may be used to investigate aquifer recharge areas, recharge rates and groundwater movement through the underlying karst aquifer.

Groundwater in Jo Daviess County is a calcium-magnesium-bicarbonate $\left(\mathrm{Ca}-\mathrm{Mg}-\mathrm{HCO}_{3}-\right)$ type groundwater with elevated concentrations of $\mathrm{Cl}^{-}$and $\mathrm{NO}_{3}-\mathrm{N}$ in some 


\begin{tabular}{|c|c|c|}
\hline Ion/Parameter & Range & $\begin{array}{l}\text { Background } \\
\text { Threshold }\end{array}$ \\
\hline $\mathrm{pH}$ & $6.35-6.90$ & $\mathrm{ND}$ \\
\hline $\begin{array}{l}\text { Specific } \\
\text { Conductance }\end{array}$ & $\begin{array}{l}520-1100 \\
\mu \mathrm{S} / \mathrm{cm}\end{array}$ & $700 * *$ \\
\hline Sodium (Na) & $\begin{array}{l}5.70-13.4 \\
\mathrm{mg} / \mathrm{L}\end{array}$ & $10 \mathrm{mg} / \mathrm{L}^{* *}$ \\
\hline Potassium $(\mathrm{K})$ & $\begin{array}{l}0.21-3.76 \\
\mathrm{mg} / \mathrm{L}\end{array}$ & $0.6 \mathrm{mg} / \mathrm{L}^{* *}$ \\
\hline Calcium $\mathrm{Ca}$ ) & $\begin{array}{l}62.2-105 \\
\mathrm{mg} / \mathrm{L}\end{array}$ & $\mathrm{ND}$ \\
\hline Magnesium (Mg) & $\begin{array}{l}35.8-56.6 \\
\mathrm{mg} / \mathrm{L}\end{array}$ & $\mathrm{ND}$ \\
\hline Silicon (Si) & $\begin{array}{l}4.5-8.0 \\
\mathrm{mg} / \mathrm{L}\end{array}$ & $\mathrm{ND}$ \\
\hline $\begin{array}{l}\text { Bicarbonate } \\
\left(\mathrm{HCO}_{3}\right)\end{array}$ & $\begin{array}{l}175-400 \\
\mathrm{mg} / \mathrm{L}\end{array}$ & ND \\
\hline Chloride (C1) & $\begin{array}{l}6.13-26.7 \\
\mathrm{mg} / \mathrm{L}\end{array}$ & $15 \mathrm{mg} / \mathrm{L}^{*}$ \\
\hline Fluoride (F) & $\begin{array}{l}0.081-0.38 \\
\mathrm{mg} / \mathrm{L}\end{array}$ & $0.4 \mathrm{mg} / \mathrm{L}^{* *}$ \\
\hline Sulfate $\left(\mathrm{SO}_{4}{ }^{2-}\right)$ & $\begin{array}{l}8.32-31.1 \\
\mathrm{mg} / \mathrm{L}\end{array}$ & $35 \mathrm{mg} / \mathrm{L}^{* * *}$ \\
\hline $\begin{array}{l}\text { Nitrate-nitrogen } \\
\left(\mathrm{NO}_{3}-\mathrm{N}\right)\end{array}$ & $\begin{array}{l}<0.30-30.1 \\
\mathrm{mg} / \mathrm{L}\end{array}$ & $2.5 \mathrm{mg} / \mathrm{L}^{*}$ \\
\hline
\end{tabular}

Table 1. The range of concentrations and estimated background threshold values for parameters and ions determined from springwater samples collected in eastern Jo Daviess County by Maas (2010). Threshold values are the upper bounds of background concentrations and were estimated based on previous work by Panno et al. (2006a, b)*, unpublished data from the sinkhole plain of southwestern Illinois (Panno, ISGS), and spring data from Hicks Spring** (Maas 2010) located in eastern Jo Daviess County. ND $=$ Not determined.

areas (Panno and Luman 2008). The background concentration range for $\mathrm{Cl}^{-}$in shallow groundwater in northern and central Illinois is between 1 and $15 \mathrm{mg} / \mathrm{L}$ (Panno et al. 2006a). The range for background concentration of $\mathrm{NO}_{3}-\mathrm{N}$ in Illinois is between 0 and $2.5 \mathrm{mg} / \mathrm{L}$ (Panno et al. 2006b; Hwang et al. 2014). Based on chemical compositions of groundwater from wells and springs, the distribution of these ions and relatively high DO concentrations ( 4.7 to $8.7 \mathrm{mg} / \mathrm{L})$ in the underlying aquifer is indicative of an open, oxygenated, unconfined karst system. Potential sources of $\mathrm{Cl}^{-}$and $\mathrm{NO}_{3}-\mathrm{N}$ include road salt, human and animal waste, and fertilizers. Water resources in open aquifer systems such as this are especially vulnerable to surface-borne contaminants. There is little or no attenuation of contaminants discharged into sinkholes, macropores and fissures; consequently, wells, springs, and streams down-gradient of contamination sources can show effects within a few days or even hours (Green et al. 2006). The convergent nature of flow in karst aquifers may result in contaminants becoming concentrated in conduits (Field 1993).

Maas (2010) sampled six springs in the eastern part of Jo Daviess County, and observed that water from five of the springs' discharges from open, oxygenated systems typically containing elevated levels of $\mathrm{Cl}^{-}$and $\mathrm{NO}_{3}-\mathrm{N}$. Nitrate- $\mathrm{N}$ concentrations were commonly greater than 10 $\mathrm{mg} / \mathrm{L}$ and as high as $30 \mathrm{mg} / \mathrm{L}$. Spring water from all six springs was undersaturated with respect to calcite and dolomite which suggests that the springs are either dominantly shallow groundwater or are a mixture of deep and shallow groundwater. The lack of saturation with respect to calcite and dolomite indicates that karstification of the Galena Dolomite is an ongoing process in this area. The elevated concentrations of $\mathrm{NO}_{3}-\mathrm{N}$ found in all but one of the springs are similar to those of tile drain waters of Illinois. Tile drains have been described by Schilling and Helmers (2008b) as analogous to karst drainage basins with regard to nutrient losses in an agricultural watershed. The elevated nutrient concentrations in the springs suggest that the springs studied by Maas (2010) may be affected by recharge water containing relatively high concentrations of surface-borne contaminants. The relative depths of the groundwater flow system feeding the springs may be estimated by the changes in temperature of the spring water with time. Specifically, the shallowest flow systems would be most affected by seasonal changes that would be manifested in the fluctuation of spring water temperatures. All but one spring were affected by seasonal changes.

Because of the nature of groundwater flow in karst aquifers, groundwater pathways may be discrete conduits/ crevices and/or bedding planes fed by numerous, smaller crevices within carbonate bedrock. Because springs are discharge points for groundwater, they may be fed by flow paths of various ages. Some of the input may have a shallow component containing surface-borne contaminants from a variety of land uses, whereas other inputs may originate from deeper, usually less contaminated, sources. The percentages of each component source can vary depending on the groundwater flow paths to the springs and with time/season.

Background concentrations of major ions and contaminants are presented in Table 1. These concentrations are from Panno et al. (2006a, b) and groundwater samples from the karst regions of southwestern Illinois, and also inferred from the water quality data from the spring 
which appears to be the least affected by recharge events and surface-borne contaminants (Maas 2010) (Table 1). There are distinct differences among the six springs based on concentrations of indicators of surface-borne contamination which include $\mathrm{K}, \mathrm{Na}, \mathrm{Cl}^{-}$, and $\mathrm{NO}_{3}-\mathrm{N}$. Maas (2010) came to slightly different conclusions using various non-site specific references (e.g., Hem 1986) that relied on ion concentrations in soils and carbonate rock to determine whether ion concentrations of the springs were above or below background threshold values. He concluded that $\mathrm{Na}$ and sulfate $\left(\mathrm{SO}_{4}^{2-}\right)$, as well as $\mathrm{Cl}^{-}$and $\mathrm{NO}_{3}-\mathrm{N}$ were anomalous and were derived from surface sources. Because the geology of Jo Daviess County is not solely carbonate rock, other strata (e.g., shale) could have contributed $\mathrm{Na}$ and $\mathrm{SO}_{4}{ }^{2-}$ to the groundwater. Potential contaminants in the area include fertilizers and road salt $(\mathrm{NaCl})$. Fertilizers used in the area include urea, $28 \%$ solution $\mathrm{N}$, anhydrous ammonia, diammonium phosphate, potash, and, on a more local basis, hog and dairy manure. The McPhillips Spring is in the vicinity of a dairy where manure is applied to the fields (Mr. Jim Frances, Warren, IL, personal communications, June 2013). Because households in this area are on private septic systems, waste from septic effluent is also a possible contaminant (Panno et al. 2007).

Preliminary work by Panno and Luman (2008) on available water quality data from public water wells from Jo Daviess and Stephenson Counties showed that $\mathrm{Cl}^{-}$concentrations ranged from less than 1 to $55 \mathrm{mg} / \mathrm{L}_{\text {and }} \mathrm{NO}_{3}-$ $\mathrm{N}$ concentrations from less than 0.1 to $31 \mathrm{mg} / \mathrm{L}$.

Denitrification probably accounts for the very low concentrations to absence of $\mathrm{NO}_{3}-\mathrm{N}$ at depths greater than 400 feet. Background concentrations may have a lower upper threshold than the estimated $15 \mathrm{mg} / \mathrm{L} \mathrm{Cl}^{-}$and the $2.5 \mathrm{mg} / \mathrm{L} \mathrm{NO}_{3}-\mathrm{N}$ (Table 1). Additional estimates for background concentrations of $\mathrm{Cl}^{-}$and $\mathrm{NO}_{3}-\mathrm{N}$ (based on municipal well data) are slightly lower, about 1 to 10 $\mathrm{mg} / \mathrm{L}$ and 0 to $2 \mathrm{mg} / \mathrm{L}$, respectively. The deeper groundwater in the area from wells that intersect the St. Peter Sandstone have $\mathrm{Cl}^{-}$concentrations between $<1$ and 3 $\mathrm{mg} / \mathrm{L}$ in Jo Daviess County and about $1 \mathrm{mg} / \mathrm{L}$ in the Galena area. Chloride concentrations in aquifers at that depth are anomalously low with the lowest concentration $(0.6 \mathrm{mg} / \mathrm{L})$ being only slightly greater than the concentration of $\mathrm{Cl}^{-}$in rainwater $(0.1$ to $0.3 \mathrm{mg} / \mathrm{L})$ and slightly less than in soil water ( 0.7 to $1.7 \mathrm{mg} / \mathrm{l})$ (Panno et al. 2006a). Processes in the unsaturated zone (e.g., evapotranspiration) and rock water interactions typically increase the $\mathrm{Cl}^{-}$concentration of groundwater up to 15 $\mathrm{mg} / \mathrm{L}$. Recharge of glacial melt water would be capable of leaching soils and bedrock aquifer flow paths to the point where they would impart little $\mathrm{Cl}^{-}$to the ground- water via rock-water interactions. This effect is apparent in part of the Mahomet Aquifer in east central Illinois (Hackley et al. 2010).

The $\mathrm{pH}$ values of spring water sampled by Maas (2010) were always below 7.0 which are consistent with the spring water being undersaturated with respect to calcite and dolomite. Water in equilibrium with calcite or dolomite would have a $\mathrm{pH}$ value of about 7.5 as noted earlier. These lower $\mathrm{pH}$ values indicate that groundwater from the springs is not in equilibrium with the carbonate rock supporting the interpretation of an open system.

Specific conductance $(\mathrm{SpC})$ is a measurement of the electrical conductance of the water that can be easily taken in the field. While SC is a very general measurement, it does yield an indication of the presence of contaminants to groundwater of surface water. The addition of contaminants (e.g., road salt) can increase the SC proportionally. The approximate background values in southwestern Illinois and northwestern Illinois groundwater are 650 and $700 \mu \mathrm{S} / \mathrm{cm}$, respectively based on available data from Maas (2010) and Panno (ISGS, unpublished data).

Potassium and $\mathrm{Cl}^{-}$concentrations in spring water suggest that at least two of the springs may have been contaminated with potash fertilizer, manure, and/or human waste. Similar effects were seen in tile drain-fed stream water samples from the same area during the same period (Maas 2010). Groundwater samples from the other springs all fall below the $\mathrm{K}$ background threshold of 0.6 $\mathrm{mg} / \mathrm{L}$ (Table 1).

Nitrate-N concentrations for most of the springs were greater than those of shallow groundwater of Illinois and far exceeded the background value of $2.5 \mathrm{mg} / \mathrm{L}$ (Table 1). Nitrate-N concentrations ranged between 2.9 and 30 $\mathrm{mg} / \mathrm{L}$ (median $=12.3 \mathrm{mg} / \mathrm{L}$ ) for five of the six springs, with all but one sample exceeding $10 \mathrm{mg} / \mathrm{L}$. These concentrations exceeded those found in tile drains of central Illinois measured by the authors (e.g., ranging from 0.51 to $23.1 \mathrm{mg} / \mathrm{L}$, median $=11.3 \mathrm{mg} / \mathrm{L}$ (Panno et al. 2005)) and in tile-drain fed surface streams in Jo Daviess County (i.e., ranging from 4.19 to $14.6 \mathrm{mg} / \mathrm{L}$, median $=9.31$ $\mathrm{mg} / \mathrm{L}$ ) (Maas 2010). The elevated levels are most likely due to the application of $\mathrm{N}$-fertilizer and manure to agricultural fields in the area. Nitrate-N concentrations in one of the springs were very low, equivalent to what Panno et al. (2006b) determined to be indicative of background conditions $(<0.4 \mathrm{mg} / \mathrm{L})$. Whereas it is possible that the low $\mathrm{NO}_{3}-\mathrm{N}$ concentration in this spring is the result of denitrification, the background-level concentration of $\mathrm{Cl}^{-}$and $\mathrm{K}$ suggest that it is more likely that the spring represents background concentrations for shallow 
groundwater in the area. Hicks Spring appears to be the least affected by anthropogenic sources and recharge events among the six springs sampled by Maas (2010), and its flow path may be deeper than the other springs.

All springs are in close proximity to land supporting row-crop agriculture and one is in close proximity to a livestock operation. However, the actual recharge areas of the springs are not known. Consequently, it is not possible at this time to use land use as an indicator of the sources of surface-borne contaminants in any more than a general way. Chloride and $\mathrm{NO}_{3}-\mathrm{N}$ concentrations in Hicks Spring are well below their background thresholds. Because background concentrations for $\mathrm{Cl}^{-}$and $\mathrm{NO}_{3}-\mathrm{N}$ are exceeded in five of the six springs and because the ions covary, the data suggest that these springs are being fed by an aquifer with a steady input of these ions. The data also suggest that the ions are entering the aquifer together perhaps as manure and/or septic effluent. A plot of $\mathrm{Na}$ vs $\mathrm{Cl}^{-}$for all spring data shows no discernible covariance, indicating that road salt $(\mathrm{NaCl})$ is not the likely source of either ion in the springs. However, there are not enough chemical data to determine the source(s) of these ions at this time.

Overall, the degree of contamination of the spring water with regard to $\mathrm{NO}_{3}-\mathrm{N}$ is greater than typically found in shallow groundwater of Illinois. This, plus the fact that concentrations of $\mathrm{K}$ and $\mathrm{Cl}^{-}$exceed background concentrations in all but one spring indicates that N-based fertilizers and/or manure/human wastes are likely entering the groundwater systems. The high DO concentrations in the spring samples (Maas 2010) suggest rapid movement of water into the subsurface which would limit attenuation within the soil zone. In situations where water recharges more slowly through the soil zone, oxygen is consumed as organic matter is reduced, resulting in anoxic conditions that promote denitrification which would decrease $\mathrm{NO}_{3}-\mathrm{N}$ concentrations. The thin soils and the presence of macropores and sinkholes in this area appear to promote rapid recharge to bedrock aquifers, a common feature of karst regions.

\section{Shallow Wells within the Galena Dolomite}

Our sampling is the first time wells in the Driftless Area of Illinois have been sampled on a systematic basis. The wells ranged from 70 feet to 160 feet in depth. As with the spring water samples, groundwater from all wells is a $\mathrm{Ca}-\mathrm{Mg}-\mathrm{HCO}_{3}$ type water with $\mathrm{pH}$ values ranging from 6.56 to 6.73 . Tritium in groundwater samples ranged from 0.60 to 5.45 tritium units (TU) (Figure 5). The concentration of tritium in today's rainfall (ca. 2014) is about 5.5 TU (Fanta, ISGS, personal communications, September 2014). The presence of tritium in the well water samples indicates that there is some component of modern recharge.

The $\mathrm{Ca}-\mathrm{Mg}-\mathrm{HCO}_{3}$ type water was expected because each well intersected the fractured and creviced Galena Dolomite aquifer. Groundwater in equilibrium with dolomite should have a pH value of about 7.5 (e.g., Parkhurst and Plummer 1993). The $\mathrm{Mg} / \mathrm{Ca}$ ratio of the samples ranged from 0.471 to 0.623 (median $=0.545$ ); pure dolomite dissolved by fresh water would have a $\mathrm{Mg} / \mathrm{Ca}$ ratio of 0.61 . Thus, most of the samples (all but one between 0.516 and 0.623 ) are consistent with dissolution of dolomite. The sample with the lowest ratio of 0.417 may be affected by a thin bed of limestone. It is clear that dolomite has not been dissolved to equilibrium within the groundwater probably due to the influx of and mixing with recent recharge.

Evidence of modern recharge is also present as surfaceborne contaminants such as $\mathrm{Na}, \mathrm{Cl}^{-}$and $\mathrm{NO}_{3}-\mathrm{N}$. Tritium does not decrease with depth, and it does not co-vary with $\mathrm{Na}$ or $\mathrm{Cl}$. This lack of correlation may be a reflection of the highly fractured and creviced nature of the Galena Dolomite aquifer and the vagaries of well drilling. Available data from wells screened within the deeper Plattville Formation and St. Peter Sandstone show anomalously low concentrations of Cl- (about $1 \mathrm{mg} / \mathrm{L}$ ). This suggests that the upper part of the Galena Dolomite aquifer is more affected by surface-borne contaminants than deeper units, as would be expected.

Nitrate-N concentrations range from below detection $(<$ $0.04 \mathrm{mg} / \mathrm{L}$ ) to $5.42 \mathrm{mg} / \mathrm{L}$; only two of the wells had $\mathrm{NO}_{3}-$ $\mathrm{N}$ concentrations that exceed the background threshold concentration of $2.5 \mathrm{mg} / \mathrm{L}$. Nitrate concentrations in the wells samples correlate well with tritium concentrations; $\mathrm{NO}_{3}-\mathrm{N}$ concentrations were below detection $(<0.04$ $\mathrm{mg} / \mathrm{L}$ ) for TU concentrations less than 3 TU (Figure 5).

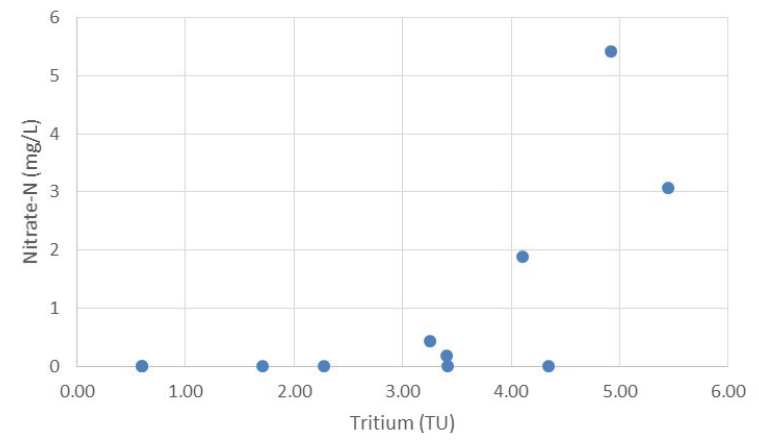

Figure 5. Nitrate concentrations decrease with time within the karst aquifer, probably due to denitrification (e.g., Panno et al. 2001). 
This shows a strong correlation between $\mathrm{NO}_{3}-\mathrm{N}$ and groundwater age may be the result of denitrification and/ or mixing with $\mathrm{NO}_{3}-\mathrm{N}$-free groundwater. Fluoride $\left(\mathrm{F}^{-}\right)$ appears to be negatively correlated with tritium (Figure 6) suggesting that $\mathrm{F}^{-}$is derived from rock-water interaction and might serve as a surrogate/proxy for tritium in this area.

Calcium and sulfate concentrations co-vary within the shallow aquifer (Figure 7). Given the abundance of pyrite and other sulfides within the Galena Dolomite, the oxidation of pyrite is probably the main source of $\mathrm{SO}_{4}{ }^{2-}$.

Delta $\delta \mathrm{D}$ and $\delta^{18} \mathrm{O}$ data from precipitation in Jo Daviess County should be similar to that of precipitation in the Chicago area. Precipitation data collected in Chicago from 1960 to 1979 (IAEA 2014) provide a local meteoric water line similar to that of the Global Meteoric Water Line. The stable isotope data for the groundwater sam-

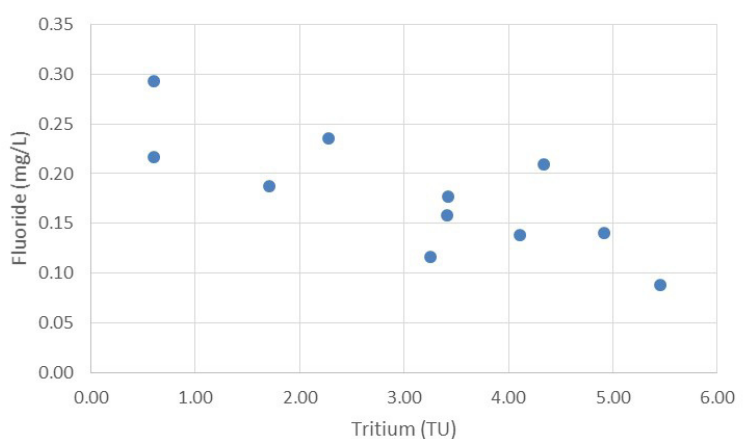

Figure 6. Fluoride and tritium are negatively correlated, suggesting that $F^{-}$increases in concentration with time within the karst aquifer, probably due to rock-water interaction.

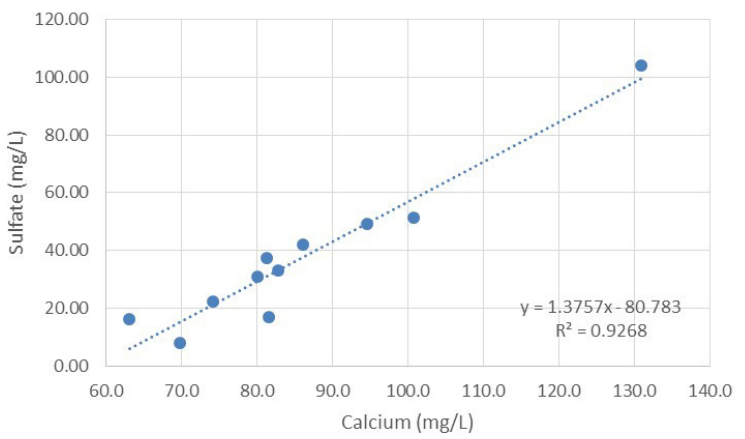

Figure 7. Sulfate vs Ca in shallow wells reveals a linear relationship that is common in groundwater. The linear relationship suggests a single source for the sulfate (i.e., the oxidation of pyrite). ples collected in Jo Daviess County fall along this line and indicate that little has occurred to the precipitation/ recharge (e.g., evaporation) prior to entering the Galena Dolomite aquifer.

Combining these data with those of the ISWS database yielded a representation of the vertical distribution of selected ions. The vertical distribution of surface borne contaminants such as $\mathrm{Cl}^{-}$and $\mathrm{NO}_{3}-\mathrm{N}$ is distinctive (Figures 8 and 9). Chloride concentrations are due, in a large part, to road salt contamination. The highest $\mathrm{Cl}^{-}$concen-

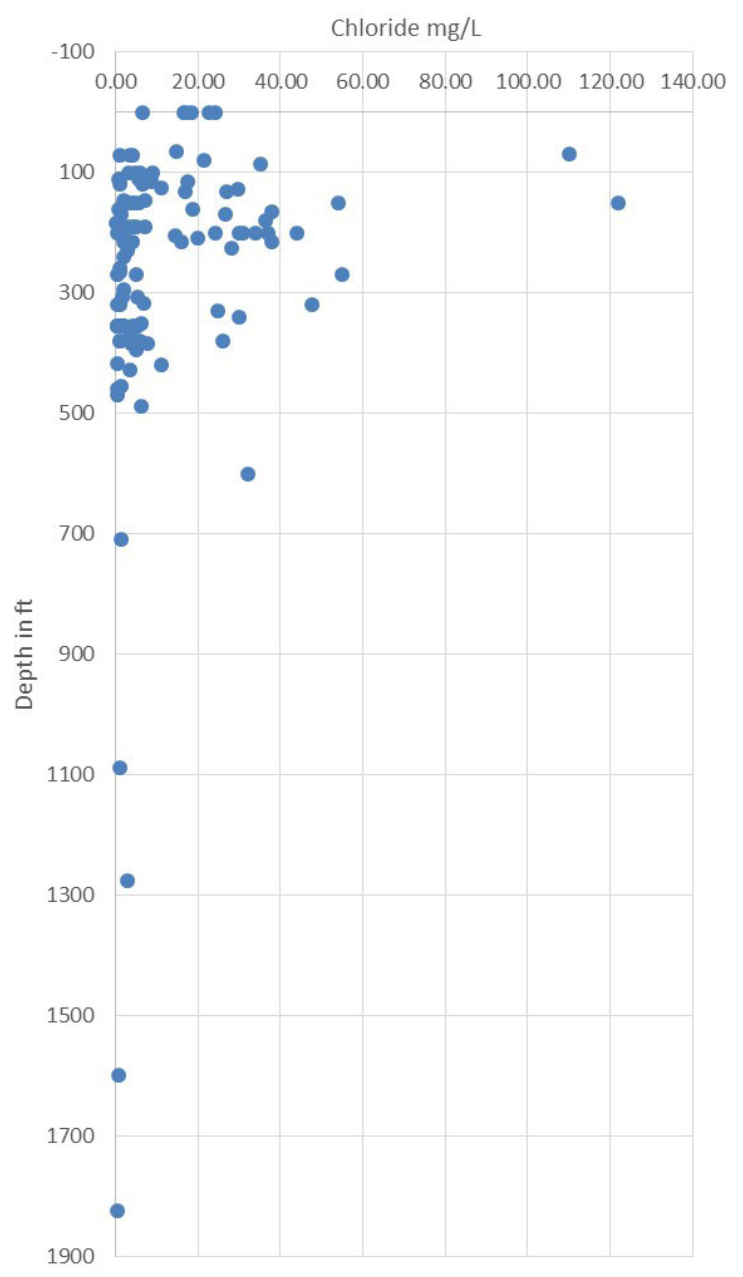

Figure 8. Chloride concentrations vs depth from private wells and springs (assumed depth of 1 foot) located in Jo Daviess County. Chloride concentrations are sporadic and elevated above natural background for shallow groundwater (15 mg/L) to depths of over 300 feet. This behavior is consistent with groundwater flow within a fractured and creviced aquifer. 


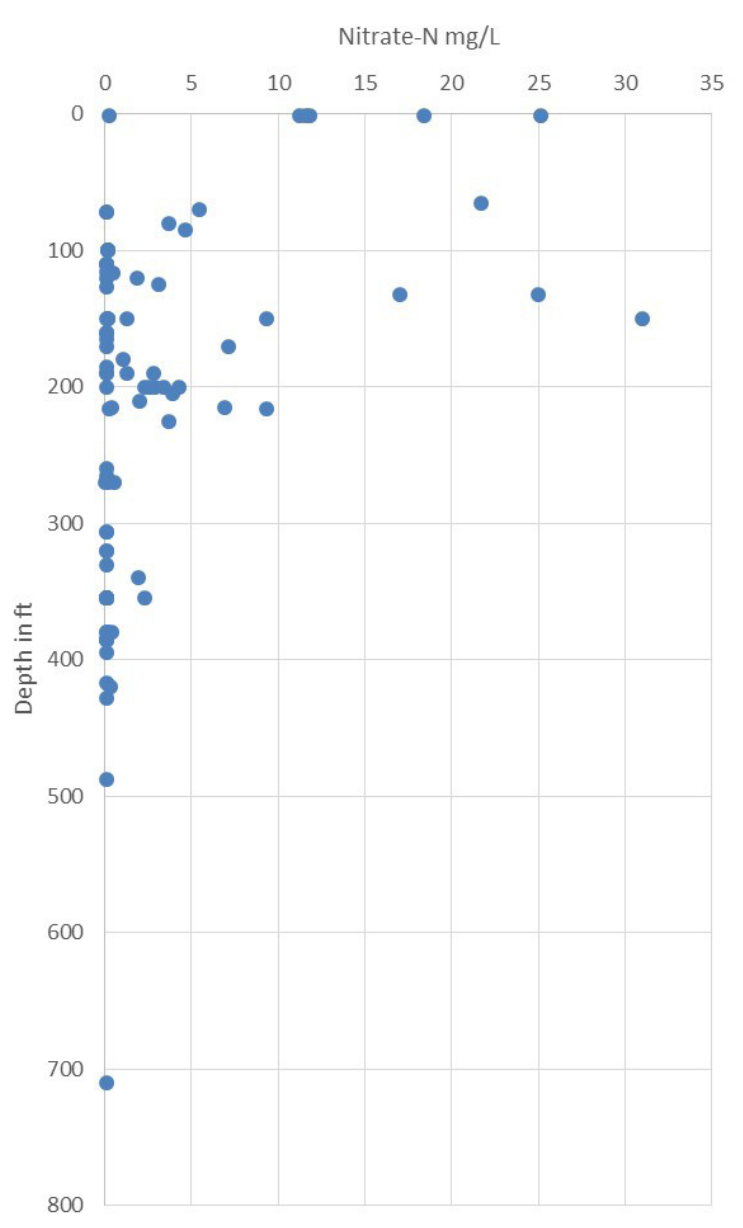

Figure 9. Nitrate-N concentrations vs depth from private wells and springs (assumed depth of 1 feet) located in Jo Daviess County. These concentrations are sporadic and elevated above natural background for shallow groundwater $(2.5 \mathrm{mg} / \mathrm{L})$ to depths of slightly over 200 feet. As with Cl, this behavior is consistent with groundwater flow within a fractured and creviced aquifer.

trations are generally found in wells less than 240 feet deep; below around 380 feet $(116 \mathrm{~m})$ deep, $\mathrm{Cl}^{-}$concentrations are always below background levels (Figure 8). The vertical distribution of surface-borne contaminants is consistent with that of a fractured and creviced karst aquifer. Elevated $\mathrm{NO}_{3}-\mathrm{N}$ concentrations are probably due to the application of $\mathrm{N}$-fertilizers in the area given that land use in Jo Daviess County is dominated by rowcrop agriculture. The relatively large $\mathrm{NO}_{3}-\mathrm{N}$ concentrations near the surface are typical of agricultural areas, but as with the $\mathrm{Cl}$ - concentrations, the sporadic nature of the profile is consistent with a fractured and creviced karst aquifer.
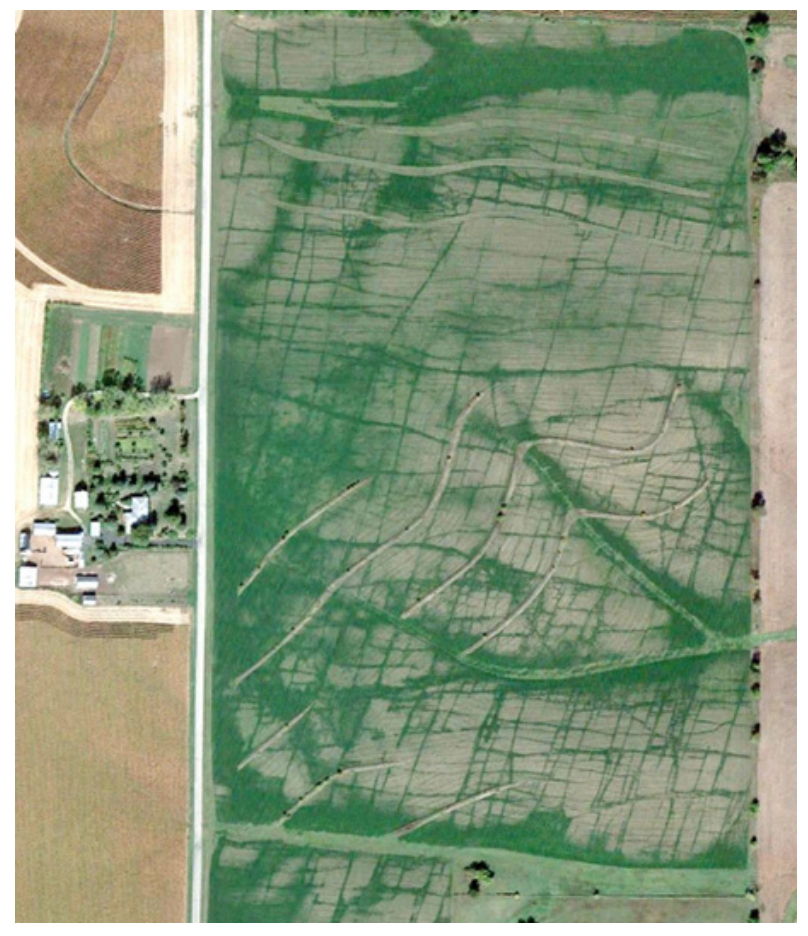

Figure 10. Croplines in a field just north of Jo Daviess County in September of 2012. The lines follow fractures and crevices that make up the porosity of the underlying karst aquifer (photograph from GoogleEarth).

Overall, the chemical composition of relatively shallow groundwater within the Galena Dolomite aquifer is consistent with that of the springs and reflects an open fractured karst aquifer whose mineralogy is dominated by dolomite. In particular, elevated $\mathrm{NO}_{3}-\mathrm{N}$ concentrations at depth are indicative of an open, oxygenated system with discrete and focused flow paths.

\section{Conceptual Hydrologic Model}

A preliminary conceptual model for the hydrogeology of the Galena Dolomite, based on previous studies in counties east of Jo Daviess County suggests that the northeast-southwest and northwest-southeast trending fractures/crevices and bedding planes constitute the greatest porosity for the Galena Dolomite aquifer (Ekberg 2008). Panno et al. (2015c) and Luman and Panno (2015) showed that these fracture/crevice systems are oriented more north-south and east-west in Jo Daviess County (Figure 10).

Based on this investigation and Panno et al. (2015b), we have documented that the Galena Dolomite has its greatest porosity within at least the upper 15 to 25 feet (4.6 to $7.6 \mathrm{~m}$ ) of the dolomite with fractures and solution- 
enlarged crevices ranging from $<0.4$ in to 3 feet $(<1 \mathrm{~cm}$ to $1 \mathrm{~m}$ ) or wider. This is in spite of fine-grained sediment found in the upper parts of crevices greater than about 0.4 inches $(1 \mathrm{~cm})$ in width; the depth of this material and its effects on groundwater flow is currently under investigation. In general, the crevices provide a network of pathways through which infiltrating surface water and groundwater can flow rapidly. Below 25 feet $(9.6 \mathrm{~m})$, many crevices become narrower and range from less than 0.25 to greater than 1 inch $(0.6$ to $2.5 \mathrm{~cm})$; east-west trending crevices tend to retain their widths of 3 feet or more with depth, thereby providing large conduits for the karst aquifer. Bedding planes may also provide pathways for groundwater movement. The effect of depth on the porosity and permeability associated with shear zones is currently under investigation. However, elevated concentrations of $\mathrm{NO}_{3}-\mathrm{N}$ and $\mathrm{Cl}^{-}$suggest the system is susceptible to surface-borne contamination to depths greater than 300 feet.

It is reasonable to assume that relatively rapid recharge to the karst aquifer occurs throughout the county, but probably less so where Maquoketa Shale is present. In areas where Maquoketa Shale constitutes the bedrock surface, and where drain tiles are used to lower the water table, relatively greater amount of recharge may discharge to streams before entering the karst aquifer. Sinkholes and macropores are present throughout the county and are locations of focused recharge. Sinkholes are not commonly seen due either to cultivation, which tends to obscure all but the very largest ones, or perhaps their natural scarcity. During dry periods, macropores (desiccation cracks) are ubiquitous and form easily due to the thinness of the soil and the depth of the water table (below the soil-rock interface) (Panno et al. 2013).

\section{References}

American Public Health Association (APHA), the American Water Works Association (AWWA), and the Water Environment Federation (WEF). 1999. Standard methods for the examination of water and wastewater 20 .

Ekberg DW. 2008. Secondary porosity development in the karstic Galena/Platteville (Trenton/Black River) dolomite on the Wisconsin Arch: Implications for triple porosity ground water flow. [Abstract], National Ground Water Association Ground Water Summit, Memphis, TN. March 30 - April 3, 2008.

Field MS. 1993. Karst Hydrology and Chemical Contamination. Journal of Environmental Systems 22 (1): $1-26$.

Frankie WT, Nelson RS. 2002. Guide to the geology of the Apple River Canyon State Park and surrounding area of northeastern Jo Daviess County, Il- linois. Illinois State Geological Survey Field Trip Guidebook. 2002B: p. 88.

Green RT, Painter SL. et al. 2006. Groundwater contamination in karst terrains. Water, Air, and Soil Pollution: Focus 6: p. 157-170.

Hackley KC, Panno SV, Hwang HH, Kelly WR. 2007. Groundwater quality of springs and wells of the sinkhole plain in southwestern Illinois: Determination of the dominant sources of nitrate. Illinois State Geological Survey Circular 570: p. 39.

Hem JD. 1985. Study and the interpretation of the chemical characteristics of natural water. U.S. Geological Survey Water-Supply Paper. 2254: p. 263.

Heyl AV Jr, Agnew AF, Lyons EJ, Behre CH Jr. 1959. The geology of the upper Mississippi Valley zinglead district. U.S. Geological Survey Professional Paper. 309: p. 62-63.

Hwang HH, Panno SV, Hackley KC. 2015. Effects of land use change on groundwater quality of northeastern Illinois, USA: A historic perspective. Environmental and Engineering Geology, v. XXI, no. 2, p. 75-90.

IEPA-IDOA. 2015. Illinois nutrient loss reduction strategy. Illinois Environmental Protection Agency and Illinois Department of Agriculture.http://www. epa.state.il.us/water/nutrient/documents/illinoisnlrs-public-comment-11-20-14.pdf

IDEXX. 2013. Colilert. IDEXX Laboratories, Inc. Westbrook Maine. Accessed October 14, 2014. Available from: https://www.idexx.com/water/ products/colilert.html

Kelly WR, Panno SV, Hackley KC. 2012. Concentrations and trends of chloride and other major ions in waters of the Chicago, Illinois region. Journal of Environmental and Engineering Geology. Special issue on the hydrogeological effects of urbanization, XVII (1): 65-81.

Lindsey BD, Katz BG, Berndt MP, Ardis AF, Skach KA. 2010. Relations between sinkhole density and anthropogenic contaminations in selected carbonate aquifers in the eastern United States. Environmental Earth Science, 60: 1073-1090.

Maas BJ. 2010. Investigation of spatial and temporal variations in water quality around Nora, IL [master's thesis]. Illinois State University, Bloomington, IL. p. 128.

McGarry CS, Riggs MH. 2000. Aquifer sensitivity map, Jo Daviess County, Illinois. Illinois State Geological Survey Open File Series OFS 2000-8i. 1: 62,500 scale.

Nelson JW. 1995. Structural features in Illinois. Illinois State Geological Survey ISGS Bulletin 100. p. 144. 
O’Riordan T, Bentham G. 1993, The politics of nitrate in the UK, in T.P. Burt, A.L. Heathwaite, and S.T. Trudgill, eds., Nitrate-Processes, patterns, and management: New York, John Wiley and Sons. p. 403-416.

Ostlund HG, Dorsey HG. 1977. Rapid electrolytic enrichment and hydrogen gas proportional counting of tritium, in Low-radioactivity measurements and applications: Proceedings of the International Conference on Low-Radioactivity Measurements and Applications. October 6-10, 1975, the Hig Tatras, Czeckoslovakia, Slvenske Pedagogike Nakladetal'stvo, Bratislava.

Panno SV, Krapac IG, and Weibel CP. 1996. Groundwater contamination in karst terrain of southwestern Illinois. Illinois State Geological Survey Environmental Geology Series. 151: p. 43.

Panno SV, Weibel CP, and Li WB. 1997. Karst regions of Illinois. Illinois State Geological Survey Open File Series 1997-2: p. 42.

Panno SV, Weibel CP, Wicks CM, and Vandike JE. 1999. Geology, hydrology, and water quality of the karst regions of southwestern Illinois and southeastern Missouri. Illinois State Geological Survey Guidebook 27, 33rd Annual Meeting, Geological Society of America, April 22-23, 1999 : p. 38.

Panno SV, Hackley KC, Hwang, HH and Kelly WR. 2001. Determination of the sources of nitrate contamination in karst springs using isotopic and chemical indicators. Chemical Geology. 179 (1-4): 113-128.

Panno SV, Hackley KC, Hwang HH, Greenberg S, Krapac IG, Landsberger S, and O'Kelly DJ. 2005. Data base for the characterization and identification of the sources of sodium and chloride. Illinois State Geological Survey Open File Series 2005-1: p. 15.

Panno SV, Hackley KC, Hwang HH, Greenberg S, Krapac IG, Landsberger S, and O'Kelly DJ 2006a. Characterization and identification of the sources of $\mathrm{Na}-\mathrm{Cl}$ in ground water. Ground Water. 44 (2): 176-187.

Panno SV, Kelly WR. Martinsek AT, Hackley KC. 2006b. Estimating background and threshold nitrate concentrations using probability graphs. Ground Water 44 (5): 697-709.

Panno SV, Kelly WR, Hackley KC, Weibel CP. 2007. Chemical and bacterial quality of discharge from on-site aeration-type wastewater treatment systems. Ground Water Monitoring Review 27 (2): 71-76.

Panno SV, Luman DE. 2008. Assessment of the geology and hydrogeology of two sites for a proposed large dairy facility in Jo Daviess County near Nora, IL. Illinois State Geological Survey Open File Series 2008-2: p. 32.

Panno SV, Luman DE, Kelly WR, Alschuler MB. 2013. The use of drought-induced "crop lines" as a tool for characterization of karst terrain. Proceedings of the Thirteenth Multidisciplinary Conference on Sinkholes and the Engineering and Envionmental Impacts of Karst: p. 9.

Panno SV, Millhouse PG, Nyboer RW, Watson D, Kelly WR, Anderson L, Abert CC, and Luman DE. 2015a. Guide to the geology, hydrogeology, archaeology, history and biotic ecology of the Driftless Area of northwestern Illinois, Jo Daviess County. Illinois State Geological Survey Field Trip Guidebook 42, 70 p.

Panno SV, Luman DE, and Kolata DR. 2015b. Characterization of karst terrain using remotely-sensed data in Jo Daviess County, Illinois. Illinois State Geological Survey Circular. 587. 29 p., 1 map, $1: 62,500$

Parkhurst DL, Plummer LN. 1993. Geochemical models, in Alley, W.M., editor. Regional ground-water quality, Chapter 9. New York (NY): Van Nostrand Reinhold. p. 199-225.

Reed PC. 2008. Spring place names and historic data on springs, licks and selected water wells in Illinois. Capitol Blueprint, Springfield, IL: p. 177.

Schilling KE, Helmers MJ. 2008a. Effects of subsurface drainage tiles on streamflow in agricultural watersheds: exploratory hydrograph analysis. Hydrological Processes 22: 4497-4506. DOI:10.1002/ hyp: 7052.

Schilling KE, Helmers MJ. 2008b. Tile drainage as Karst: Conduit flow and diffuse flow in a tiledrained watershed. Journal of Hydrology. 349: 291-301.

Trowbridge AC, Shaw EW. 1916. Description of the Galena and Elizabeth quadrangles. Illinois State Geological Survey Bulletin. 26: p. 233.

USEPA 2014. Sodium in drinking water. U.S. Environmental Protection Agency Contaminant Candidate. Available from: drinkingwater/dws/ccl/sodium. cfm.http://water.epa.gov/scitech/drinkingwater/ dws/ccl/sodium.cfm

Weibel CP, Panno SV. 1997. Karst terrains and carbonate bedrock of Illinois. Illinois State Geological Survey, Illinois Map Series 8, 1:500,000 Scale.

Willman HB, Frye JC. 1970. Pleistocene stratigraphy of Illinois. Illinois State Geological Survey Bulletin. 94: p. 204. 
